\title{
Key Plant, Key Pests: Crapemyrtle (Lagerstroemia) ${ }^{1}$
}

\author{
Juanita Popenoe, Caroline R. Warwick, and Chris Marble ${ }^{2}$
}

\section{Key Plant: Crapemyrtle (Lagerstromia)}

After being introduced to the southern United States over one hundred and fifty years ago, crapemyrtle has become one of the most common landscape plants in north and central Florida, and can commonly be found in USDA hardiness zones 7 to 9 (United States National Arboretum 2004). Crapemyrtle derived its name from its crepe-like, crinkled petals and its leaves' resemblance to a myrtle. Crapemyrtle varieties vary in size. They can be used in a range of landscape settings, including hanging baskets, groundcover, container plants, and medium-sized trees. Crapemyrtle comes in a wide variety of colors, including purple, lavender, white, pink, and red, with some cultivars

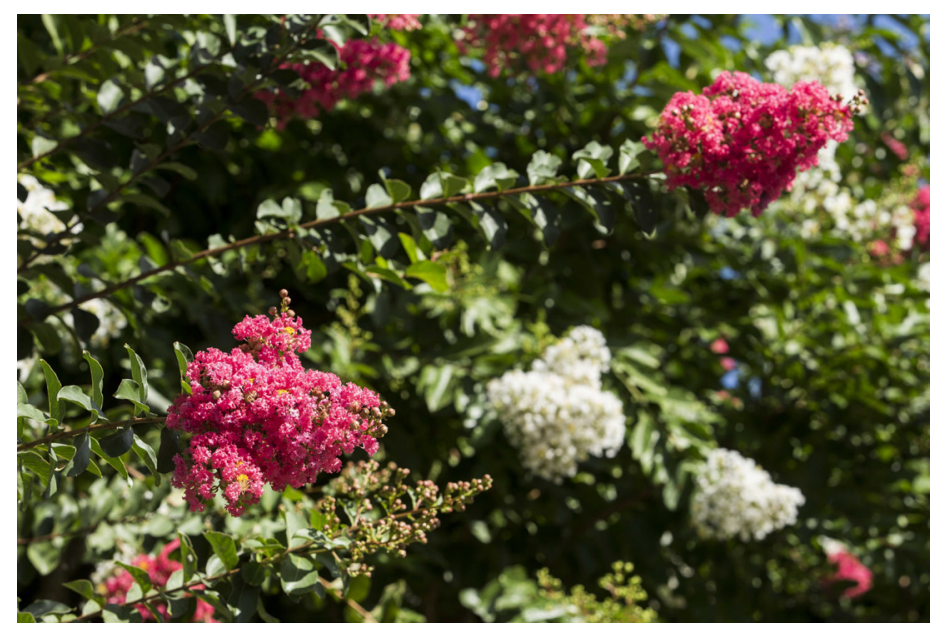

Figure 1. Crapemyrtle blooms.

Credits: Tyler Jones, UF/IFAS even displaying bicolor flowers, some of which are shown in Figure 1. Trees have an interesting peeling, smooth bark. There are 56 species of crapemyrtle native to woodlands and forests of India, China, and southeast Asia, with the most commonly cultivated species being $L$. indica, speciosa, fauriei, and indica $\mathrm{x}$ fauriei hybrids. Most varieties of crapemyrtle tend to be pest-resistant, tolerant of a wide range of soil pHs, and extremely drought tolerant, making them ideal for use in Florida landscapes (Knox 2016).

\section{Key Pests: Crapemyrtle}

This series of Key Plant, Key Pests publications are designed for Florida gardeners, horticulturalists, and landscape professionals to help identify common pests associated with common Florida flora. This publication, the third in the Key Plant, Key Pests series, helps identify the most common pests found on the crapemyrtle (Lagerstroemia). Crapemyrtle are known for being one of the most pest-free landscape plants.

This publication provides information and general management recommendations for the crapemyrtle aphid, metallic beetles, and powdery mildew. For a more comprehensive guide to woody ornamental insect management, download the current Professional Disease Management Guide for Ornamental Plants or the Integrated Pest Management in the Commercial Ornamental Nursery Guide.

1. This document is ENH1296, one of a series of the Environmental Horticulture Department, UF/IFAS Extension. Original publication date June 2018. Visit the EDIS website at http://edis.ifas.ufl.edu.

2. Juanita Popenoe, multi-county commercial fruit production agent IV; Caroline Roper Warwick, science communication specialist; and Chris Marble, assistant professor; UF/IFAS Extension, Mid-Florida Research and Education Center, Apopka, FL 32703.

The Institute of Food and Agricultural Sciences (IFAS) is an Equal Opportunity Institution authorized to provide research, educational information and other services

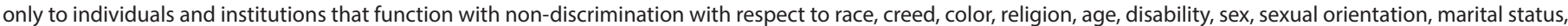

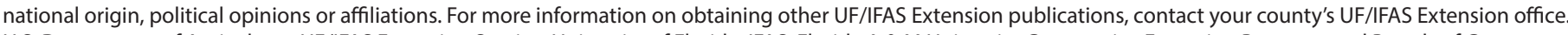
U.S. Department of Agriculture, UF/IFAS Extension Service, University of Florida, IFAS, Florida A \& M University Cooperative Extension Program, and Boards of County Commissioners Cooperating. Nick T. Place, dean for UF/IFAS Extension. 


\section{Crapemyrtle Aphid (Tinocallis kahawaluokalani)}

Recognition: Crapemyrtle aphids are 1/8 inch long, pear-shaped, pale yellow, and have two cornicles or "tailpipes." The winged forms have black markings on their wings (Figure 2). They are found mostly on the undersides of the leaves. Aphids secrete honeydew, on which sooty mold (Figure 3) grows prolifically. Sooty mold is often the first thing people notice, but it is evidence that the aphid infestation is already well-established. Their feeding may cause distortion of new growth.

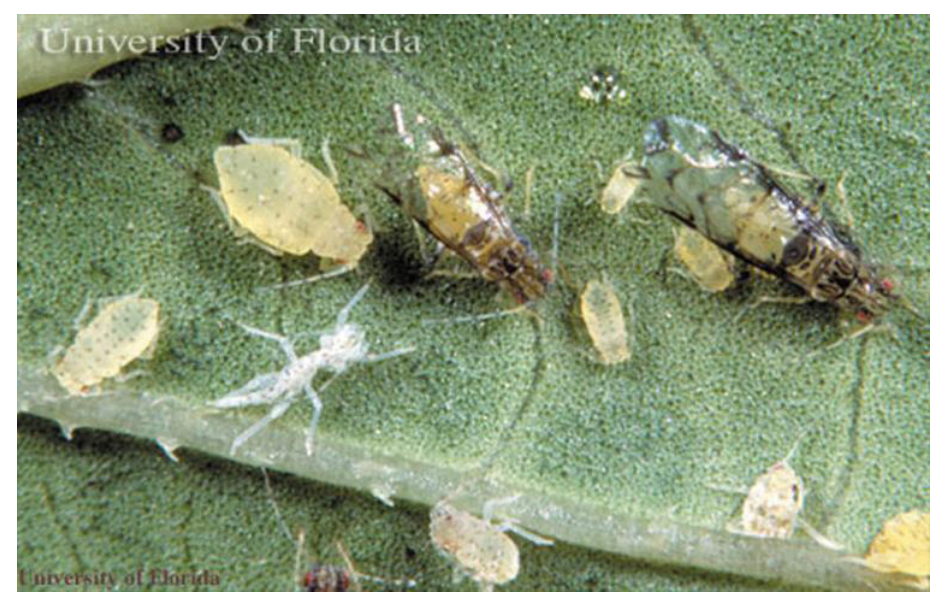

Figure 2. Crapemyrtle aphid adults, nymphs, and cast skin. Credits: University of Florida

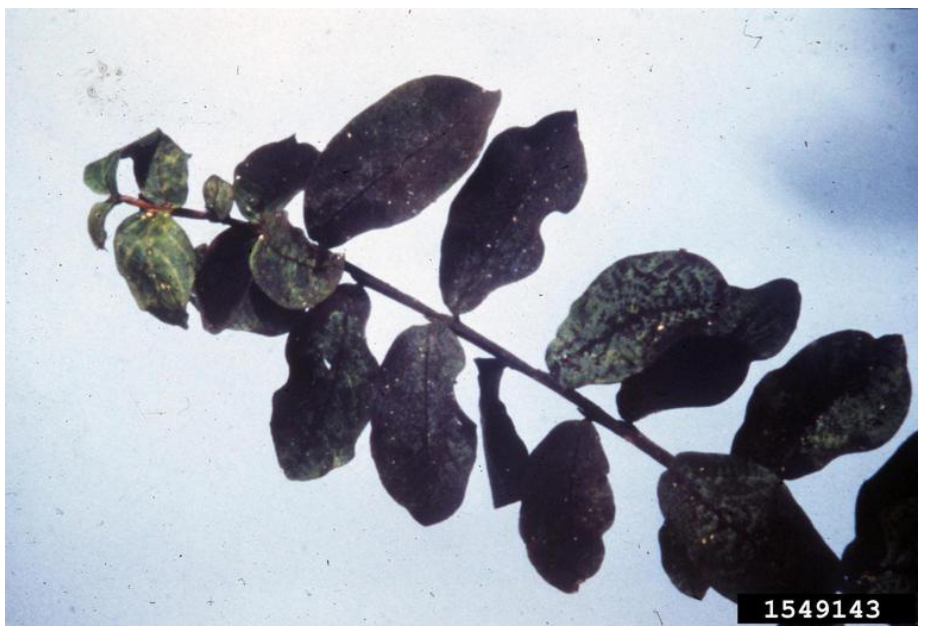

Figure 3. Sooty mold caused by aphid honeydew on crapemyrtle leaves.

Credits: Jim Baker, North Carolina State University, bugwood.org

Contributing Factors: Crapemyrtle aphids are hostspecific, and appear each year in late spring, remaining until the leaves drop in the fall. Powdery mildew-resistant varieties of crapemyrtle appear to be highly susceptible to the aphids.

Management Recommendations: If the sooty mold can be tolerated, the crapemyrtle aphid can be helpful in attracting many beneficial insects to the landscape. Insecticidal soaps, oils, or approved insecticides may be used to control aphid populations if necessary (Herbert and Mizell 2015).

\section{Metallic Flea Beetles (Altica spp.)}

Recognition: Small blue or green metallic flea beetles feed on leaf surfaces and edges. As they feed, they create shallow pits and irregular, often rounded holes in leaves (Figure 4).

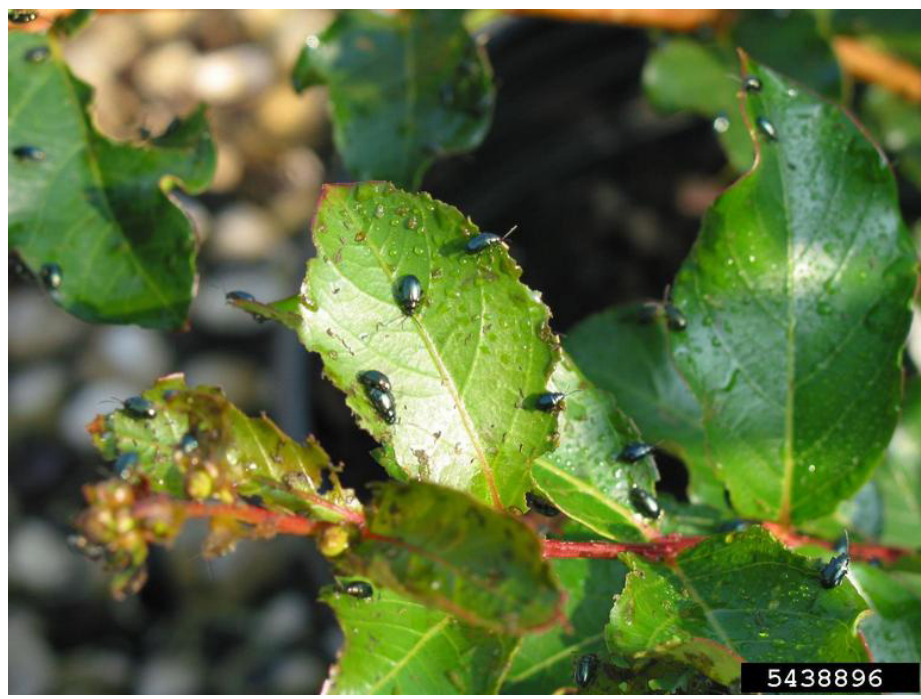

Figure 4. Water primrose flea beetle (Altica litigata) on crapemyrtle leaves.

Credits: John Olive, Auburn University, bugwood.org

Contributing Factors: Adult flea beetles overwinter near where they emerged, often in leaf litter and wooded areas. During the spring, larvae emerge and are common in vegetable gardens.

Management Recommendations: Damage is usually insignificant, but yellow sticky traps can be used for detection. Control is difficult due to the mobility of the insect; however, weeding around sites and throwing away old debris can minimize food sources and cover. Mature plants are more tolerant of feeding damage, and warmer temperatures will help plants outgrow the damage (Burkness and Hahn 2007).

\section{Crapemyrtle Bark Scale (Eriococcus lagerstroemiae)}

Recognition: An early symptom of crapemyrtle bark scale is black sooty mold covering extensive areas of leaves and stems as a result of honeydew exuded by the scale (Figure 5). Individual scale insects are white to gray in color and ooze pink when crushed (Figure 6). Large populations build up in branch crotches and disperse along branches, appearing crusty white to gray. This scale usually is not 


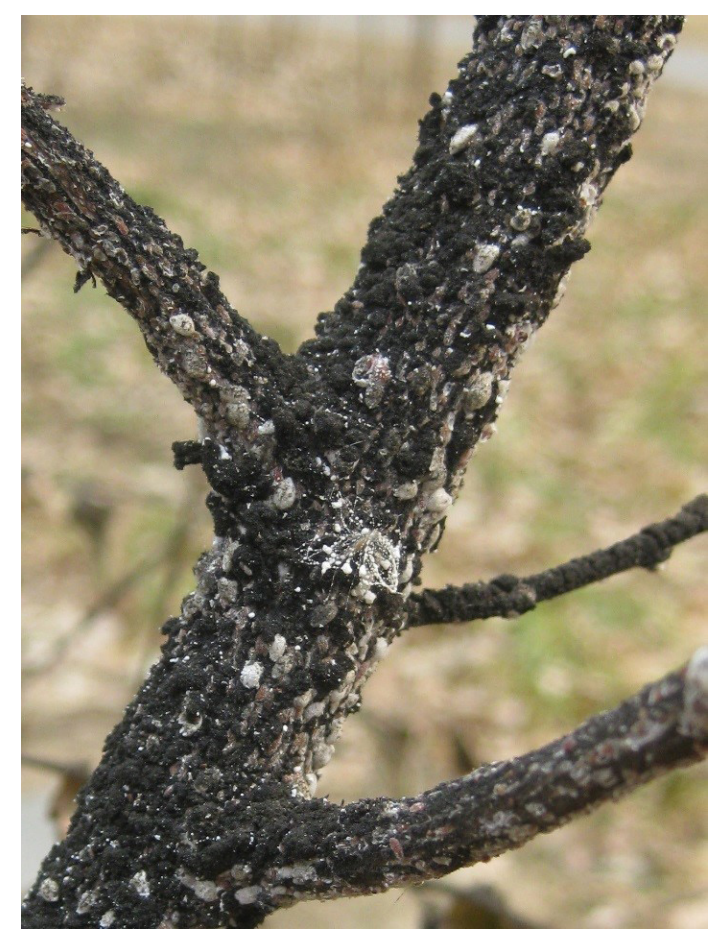

Figure 5 . Note the black sooty mold coating the layers of white and grey scale, believed to be crapemyrtle bark scale, Eriococcus lagerstroemige.

Credits: Gary Knox,UF/IFAS

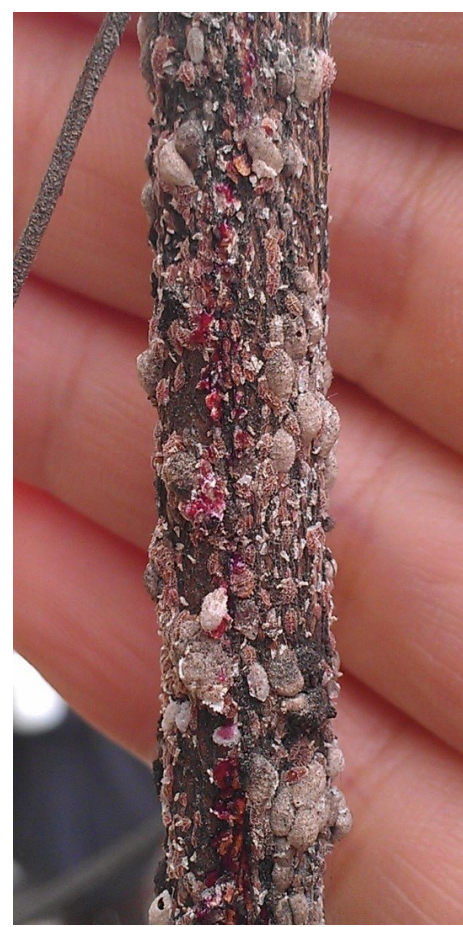

Figure 6. This white and grey colored scale oozes pink when crushed. Credits: Gary Knox, UF/IFAS

present on new growth, leaves, or slender stems unless infestations are heavy.

Contributing Factors: Due to the newness of this pest, not much information is available. For the most up-to-date information about crapemyrtle bark scale, including a map of reported outbreaks, visit the Crapemyrtle Bark Scale page on the Early Detection and Distribution Mapping System website.

Management Recommendations: This scale is a new pest and difficult to control. Inspect infested plant material to ensure you do not spread the infestation. Systemic insecticides have shown the most promise for control when applied to the root zone as a soil injection or drench. Horticultural oil has not yet been shown to be effective against this insect. For heavy infestations, wash the trunk and reachable limbs with a soft brush and mild solution of dishwashing soap and water. This will remove many of the female scales and egg masses, making insecticide control more effective. Washing will also remove much of the black mold that builds up on the bark of infested trees. Some lady beetle species, especially the twice-stabbed lady beetle, are effective predators of this scale. However, control by lady beetles is often insufficient or too late in the season to control heavy infestations and prevent aesthetic damage (Early Detection and Distribution Mapping System 2017).

\section{Powdery Mildew (Oidium sp./Erysiphe lagerstroemiae)}

Recognition: The fungus grows on the surface as a white powdery covering on leaves, shoots, and buds (Figure 7). The disease causes leaf curling and growth distortion.

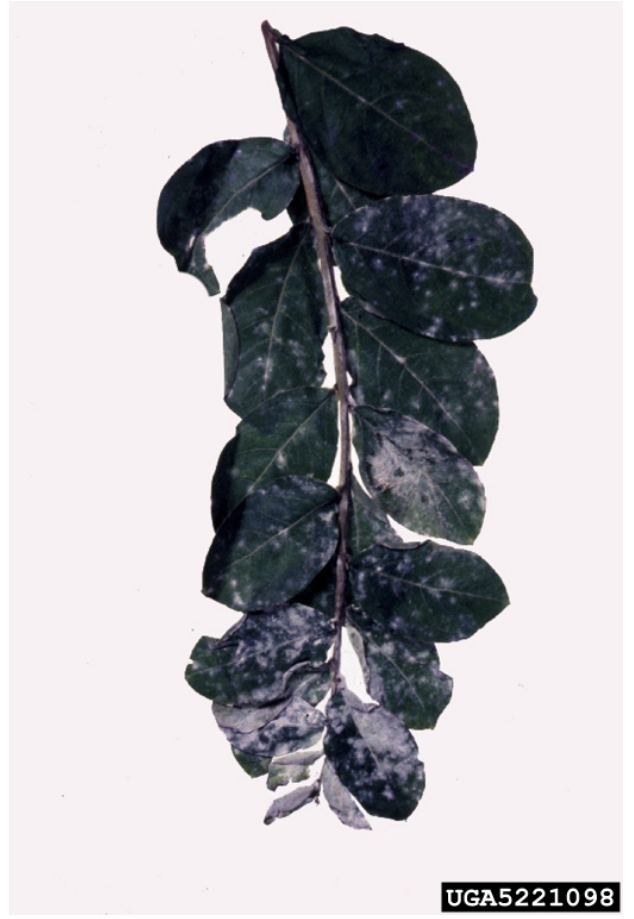

Figure 7. Powdery mildew damage on crapemyrtle leaves. Credits: Florida Division of Plant Industry, Florida Department of Agriculture and Consumer Services, bugwood.org 
Contributing Factors: Powdery mildew is most active in the cool, dry periods of spring and fall. It is most severe in shady locations.

Management Recommendations: Resistant varieties are available. Use approved fungicides when conditions favor disease development (Zhang, Palmateer, and Pernezny 2017).

\section{Additional Information}

For more information on identifying and managing pests of crapemyrtle, please contact your local UF/IFAS Extension Office for assistance. Contact information for your local office can be found on the UF/IFAS Solutions for Your Life website, http://sfyl.ifas.ufl.edu/find-your-local-office/.

\section{References}

Burkness, S. and J. Hahn. 2007. Flea beetles in home gardens. Extension publication no. M1210. St. Paul: University of Minnesota Extension.

Herbert, J. and and R. F. Mizell, III. 2015.Crapemyrtle aphid, Tinocallis kahawaluokalani (Kirkaldy). EENY-365. Gainesville: University of Florida Institute of Food and Agricultural Sciences. http://edis.ifas.ufl.edu/in663

Knox, G. W. 2016. Crapemyrtle in Florida. ENH-52. Gainesville: University of Florida Institute of Food and Agricultural Sciences. http://edis.ifas.ufl.edu/mg266

United States National Arboretum. 2004. "Crapemyrtle FAQ 2." Last modified on October 14. http://www.usna. usda.gov/Gardens/faqs/crapemyrtlefaq2.html

Zhang, S., Palmateer, A. and Pernezny, K. 2017. Florida Plant Disease Management Guide: Beans. PDMG-V3-33. Gainesville: University of Florida Institute of Food and Agricultural Sciences. http://edis.ifas.ufl.edu/pg041

Early Detection and Distribution Mapping System. 2017. "What is the Crapemyrtle Bark Scale?" Last modified December 14. http://www.eddmaps.org/cmbs/ 